\title{
Chất lượng dịch vụ tổ chức hội chọ̣, triển lãm thương mại nước ngoài
}

\section{Service quality of overseas trade exhibitions and fairs}

\author{
Cao Minh Trí ${ }^{1 *}$, Nguyễn Khánh ${ }^{2}$ \\ ${ }^{1}$ Trường Đại học Mở Thành Phố Hồ Chí Minh, Việt Nam \\ ${ }^{2}$ Trung tâm Xúc tiến Thương mại và Đầu tư Thành phố Hồ Chí Minh, Việt Nam \\ *Tác giả liên hệ, Email: tri.cm@ou.edu.vn
}

THÔNG TIN

DOI: $10.46223 /$ HCMCOUJS. econ.vi.13.1.530.2018

Ngày nhận: 13/07/2017

Ngày nhận lại: 17/10/2017

Duyệt đăng: 17/10/2017

Tù khóa:

chất lượng dịch vụ, hội chợ, triển lãm thương mại nước ngoài

\section{TÓM TẮT}

Mục tiêu nghiên cứu là đánh giá chất lượng dịch vụ tổ chức hội chợ, triển lãm thương mại nước ngoài của Trung tâm Xúc tiến Thương mại và Đầu tư (Thành phố Hồ Chí Minh, Việt Nam) thông qua sự chênh lệch giữa mức độ kỳ vọng của doanh nghiệp và mức độ thực hiện dịch vụ. Nghiên cứu được thực hiện thông qua ba giai đoạn gồm hai giai đoạn nghiên cứu định tính và một giai đoạn nghiên cứu định lượng, với đối tượng khảo sát là các chuyên gia và đại diện 200 doanh nghiệp Việt Nam đã tham gia các hội chợ, triển lãm này. Ngoài việc bổ sung khoảng trống nghiên cứu về chất lượng dịch vụ tổ chức hội chợ, triển lãm thương mại nước ngoài, nghiên cứu này đã xác định được 21/33 yếu tố có mức độ thực hiện dịch vụ đáp ứng lớn hơn hoặc bằng kỳ vọng của doanh nghiệp, 12/33 yếu tố có mức độ thực hiện dịch vụ thấp hơn kỳ vọng của doanh nghiệp và xác định sự khác biệt về mức độ kỳ vọng giữa nhóm doanh nghiệp lớn và doanh nghiệp có quy mô vừa và nhỏ cũng như giữa nhóm doanh nghiệp có vốn đầu tư nhà nước và nhóm các doanh nghiệp còn lại. $\mathrm{Ba}$ nhóm hàm ý quản trị cũng đã được đề xuất dựa trên kết quả nghiên cứu.

\begin{abstract}
The purpose of the research is to assess the service quality of overseas trade exhibitions and fairs from The Investment and Trade Promotion Center of HCMC through the disparity between enterprises' expectations and service performance. The study was conducted through three phases including two qualitative phases and one quantitative phase. Respondents who were familiar with those exhibitions and fairs were carefully selected from 200 Vietnamese enterprises for the interview. Besides bridging the
\end{abstract}


Keywords:

fairs, overseas trade exhibitions, service quality

research gap in the literature on the service quality of overseas trade exhibitions and fairs, this study found out 21 out of 33 factors that were highly appreciated when the service performance exceeded or matched their expectations and 12 out of 33 factors which were not fully appreciated when the service performance fell short of their expectations. It also identified the differences in the expectations between large enterprises and small and medium-sized ones as well as state-owned enterprises and others. Three groups of managerial implications have been suggested based on the study results.

\section{Sự cần thiết của nghiên cứu}

Doanh nghiệp có vị trí đặc biệt quan trọng của nền kinh tế, là bộ phận chủ yếu tạo ra tổng sản phẩm trong nước (GDP). Nhận thức được tầm quan trọng đó, những năm gần đây, chính quyền Thành phố Hồ Chí Minh (TP.HCM) đã thực hiện nhiều biện pháp hỗ trợ doanh nghiệp như: Xây dựng Quỹ hỗ trợ khởi nghiệp; Tổ chức các hội thảo, tập huấn giúp doanh nghiệp nâng cao năng lực cạnh tranh ở thị trường trong và ngoài nước; Phối hợp với các ngân hàng thương mại xây dựng các gói tín dụng ưu đãi dành cho các doanh nghiệp; Đặc biệt là chú trọng đẩy mạnh hoạt động xúc tiến thương mại thông qua việc tổ chức các hội chợ, triển lãm thương mại nước ngoài.

Trung tâm Xúc tiến Thương mại và Đầu tư TP.HCM (ITPC) được Ủy ban nhân dân TP.HCM giao nhiệm vụ tổ chức nhiều chương trình hội chợ, triển lãm thương mại nước ngoài tại các quốc gia, vùng lãnh thổ như: Hồng Kông, Thái Lan, Lào, Myanmar và Campuchia với quy mô tăng dần qua các năm. Nguồn kinh phí tổ chức là $50 \%$ được cấp từ ngân sách nhà nước và $50 \%$ từ các doanh nghiệp tham gia.

Thực tế cho thấy việc đánh giá chất lượng dịch vụ tổ chức các hội chợ, triển lãm thương mại nước ngoài này chỉ thông qua những số liệu thống kê ước lượng từ phía ITPC, thiếu đi sự chính xác do chưa chú trọng đến việc xác định kỳ vọng của doanh nghiệp trước khi sự kiện diễn ra và đánh giá của họ về mức độ thực hiện dịch vụ sau khi sự kiện kết thúc. Trên thế giới cũng có ít nghiên cứu về việc đánh giá chất lượng dịch vụ tổ chức hội chợ, triển lãm thương mại nước ngoài thông qua sự chênh lệch về mức độ kỳ vọng và mức độ thực hiện dịch vụ.

Nghiên cứu "Chất lượng dịch vụ tổ chức Hội chợ, Triển lãm thương mại nước ngoài” được thực hiện nhằm các mục tiêu: Đánh giá chất lượng dịch vụ tổ chức hội chợ, triển lãm thương mại nước ngoài của ITPC thông qua sự chênh lệch giữa mức độ thực hiện dịch vụ và mức độ kỳ vọng của doanh nghiệp; Kiểm định sự khác biệt mức độ kỳ vọng về chất lượng dịch vụ tổ chức hội chợ, triển lãm thương mại nước ngoài giữa các loại hình và quy mô doanh nghiệp. Từ đó, đưa ra các hàm ý quản trị nhằm nâng cao chất lượng dịch vụ tổ chức hội chợ, triển lãm thương mại nước ngoài của ITPC, hỗ trợ doanh nghiệp Việt Nam xúc tiến thương mại một cách hiệu quả cao nhất. 


\section{Cơ sở lý luận}

Theo Luật Thương mại năm 2005 của nước Cộng hòa xã hội chủ nghĩa Việt Nam (Quốc hội, 2005):

"Hội chợ, Triển lãm thuơng mại là hoạt động xúc tiến thuong mại được thực hiện tập trung trong một thời gian và tại một địa điểm nhất định để thương nhân trung bày, giới thiệu hàng hóa, dịch vu nhằm mục đích thúc đẩy, tìm kiếm co hội giao kết hợp đồng mua bán hàng hóa, hơp đồng dịch vụ”.

Hội chợ, triển lãm thương mại nước ngoài do ITPC tổ chức là hội chợ, triển lãm thương mại tổng hợp; Các doanh nghiệp tham gia có sự đa dạng về ngành nghề và chủng loại sản phẩm, loại hình cũng như quy mô doanh nghiệp (Theo Nghị định số 56/2009/NĐ-CP của Chính phủ thì: doanh nghiệp có quy mô lớn là doanh nghiệp có tổng nguồn vốn lớn hơn 100 tỷ đồng hoặc số lượng nhân viên lớn hơn 300 người; Doanh nghiệp có quy mô nhỏ và vừa có tổng nguồn vốn nhỏ hơn 100 tỷ đồng hoặc số lượng nhân viên nhỏ hơn 300 người). Do chi phí tham gia hội chợ, triển lãm thương mại nước ngoài tương đối cao nên các doanh nghiệp có sự kỳ vọng vào chất lượng dịch vụ tổ chức cũng cao. Kết quả thu được sau khi tham gia hội chợ, triển lãm thương mại nước ngoài là cơ sở để doanh nghiệp hoạch định/điều chỉnh chiến lược phát triển, chiến lược kinh doanh trong tương lai và ý định tiếp tục tham gia các lần sau.

Chất lượng dịch vụ được xem là phương thức tiếp cận quan trọng trong quản lý cạnh tranh nhằm đảm bảo sự hài lòng của khách hàng, đồng thời tăng cường khả năng cạnh tranh và hiệu quả của ngành (Kumar, Manjunath, \& Kumar, 2012). Parasuraman, Zeithaml, và Berry (1988) cho rằng chất lượng dịch vụ là khoảng cách giữa sự kỳ vọng của khách hàng và mức độ cảm nhận của họ khi đã sử dụng qua dịch vụ. Theo quan điểm của Kotler và Amstrong (2010), chất lượng dịch vụ được định nghĩa là khả năng của một dịch vụ bao gồm độ bền tổng thể, độ tin cậy, độ chính xác, sự dễ vận hành, dễ sửa chữa và các thuộc tính có giá trị khác để thực hiện các chức năng của nó. Ngoài ra, do môi trường văn hóa, người tiêu dùng ở mỗi quốc gia khác nhau có thể nhận thức khác nhau về chất lượng dịch vụ (Malhotra, Ulgado, Agarwal, \& Shainesh, 2005; T. M. T. Nguyen, 2006).

- Cơ sở lý thuyết và những mô hình đánh giá chất lượng dịch vụ đã được nhiều nhà khoa học trên thế giới nghiên cứu, trong đó có thể kể đến các công trình nghiên cứu như Bảng 1.

\section{Bảng 1}

Các mô hình đánh giá chất lượng dịch vụ

\begin{tabular}{|l|l|l|l|}
\hline \multicolumn{1}{|c|}{ Tác giả } & \multicolumn{1}{|c|}{$\begin{array}{c}\text { Tên } \\
\text { mô hình }\end{array}$} & \multicolumn{1}{c|}{$\begin{array}{c}\text { Khía cạnh } \\
\text { đo lường }\end{array}$} & \multicolumn{1}{c|}{ Đặc điểm } \\
\hline $\begin{array}{l}\text { Gronroos } \\
\mathbf{( 1 9 8 4 )}\end{array}$ & $\begin{array}{l}\text { Mô hình chất } \\
\text { lượng kỹ } \\
\text { thuật - chức } \\
\text { năng }\end{array}$ & $\begin{array}{l}\text { Chất lượng kỹ thuật } \\
\text { và chất lượng chức } \\
\text { năng }\end{array}$ & $\begin{array}{l}\text { Chất lượng dịch vụ phụ thuộc vào } \\
\text { chất lượng kỹ thuật, chất lượng } \\
\text { chức năng và hình ảnh công ty. } \\
\text { Chất lượng chức năng quan trọng } \\
\text { hơn chất lượng kỹ thuật. Tuy nhiên }\end{array}$ \\
\hline
\end{tabular}




\begin{tabular}{|c|c|c|c|}
\hline Tác giả & $\begin{array}{c}\text { Tên } \\
\text { mô hình }\end{array}$ & $\begin{array}{l}\text { Khía cạnh } \\
\text { đo lường }\end{array}$ & Đặc điểm \\
\hline & & & $\begin{array}{l}\text { mô hình chưa đưa ra lời giải thích } \\
\text { làm thế nào để đo lường chất lượng } \\
\text { kỹ thuật và chất lượng chức năng. }\end{array}$ \\
\hline $\begin{array}{l}\text { Parasuraman, } \\
\text { Zeithaml, và } \\
\text { Berry (1985) }\end{array}$ & $\begin{array}{l}\text { Mô hình chất } \\
\text { lượng } \\
\text { khoảng cách }\end{array}$ & $\begin{array}{l}\text { Bao gồm } 10 \text { khía } \\
\text { cạnh đo lường (tin } \\
\text { cậy, đáp ứng, sự } \\
\text { đảm bảo, lịch sự, } \\
\text { tiếp cận, thông tin, } \\
\text { tín nhiệm, hiểu biết } \\
\text { khách hàng, an } \\
\text { toàn, phương tiện } \\
\text { hữu hình). }\end{array}$ & $\begin{array}{l}\text { Mô hình là một công cụ phân tích, } \\
\text { cho phép nhà quản lý xác định một } \\
\text { cách có hệ thống các khoảng cách } \\
\text { chất lượng giữa một loạt các biến } \\
\text { có ảnh hướng đến chât lượng cung } \\
\text { cấp. Có khả năng hỗ trợ nhà quản } \\
\text { lý xác định các yếu tố chất lượng } \\
\text { dịch vụ liên quan dưới gốc độ } \\
\text { khách hàng. Tuy nhiên mô hình } \\
\text { chưa giải thích các trình tự đo } \\
\text { lường rõ ràng để đo lường các } \\
\text { khoảng cách ở các cấp độ khác } \\
\text { nhau. }\end{array}$ \\
\hline $\begin{array}{l}\text { Parasuraman } \\
\text { và cộng sự } \\
\text { (1988) }\end{array}$ & $\begin{array}{l}\text { Mô hình } \\
\text { SERVQUAL } \\
\text { với } 5 \text { thành } \\
\text { phần }\end{array}$ & $\begin{array}{l}\text { Bao gồm } 5 \text { khía } \\
\text { cạnh đo lường: (1) } \\
\text { Sự tin cậy, (2) sự } \\
\text { đáp ứng, (3) sự đảm } \\
\text { bảo, (4) sự đồng } \\
\text { cảm và (5) phương } \\
\text { tiện hữu hình }\end{array}$ & $\begin{array}{l}\text { Từ } 10 \text { thành phần đo lường chất } \\
\text { lượng dịch vụ năm } 1985 \\
\text { Parasuraman và cộng sự (1988) đã } \\
\text { kết hợp các biến có tính tương quan } \\
\text { lại với nhau và giảm xuống còn } 5 \\
\text { thành phần như: (1) Sự tin cậy, (2) } \\
\text { Sự đáp ứng, (3) Sự đảm bảo, (4) Sự } \\
\text { đồng cảm và (5) Phương tiện hữu } \\
\text { hình và đưa ra bộ thang đo } \\
\text { SERVQUAL gồm } 22 \text { biến quan sát } \\
\text { để đo lường chất lượng kỳ vọng và } \\
\text { dịch vụ cảm nhận của khách hàng. }\end{array}$ \\
\hline $\begin{array}{l}\text { Cronin và } \\
\text { Taylor } \\
\text { (1992) }\end{array}$ & $\begin{array}{l}\text { Mô hình } \\
\text { đánh giá dựa } \\
\text { trên kết quả } \\
\text { thực hiện }\end{array}$ & $\begin{array}{l}\text { Sử dụng thang đo } \\
\text { SERVQUAL } \\
\text { nhưng chỉ đánh giá } \\
\text { về kết quả thực hiện } \\
\text { dịch vụ. }\end{array}$ & $\begin{array}{l}\text { Chất lượng dịch vụ được định nghĩa } \\
\text { và đo lường như "một thái độ", } \\
\text { thang đo ngắn gọn hơn mô hình } \\
\text { SERVQUAL. Tuy nhiên, mô hình } \\
\text { này là chưa quan tâm đến kỳ vọng } \\
\text { của khách hàng về chất lượng dịch } \\
\text { vụ. }\end{array}$ \\
\hline $\begin{array}{l}\text { Kumar, Kee, } \\
\text { và Manshor } \\
(2009)\end{array}$ & $\begin{array}{l}\text { Mô hình chất } \\
\text { lượng } \\
\text { khoảng cách }\end{array}$ & $\begin{array}{l}\text { Kế thừa nghiên cứu } \\
\text { của tác giả } \\
\text { Parasuraman và }\end{array}$ & $\begin{array}{l}\text { Giải thích các trình tự đo lường rõ } \\
\text { ràng để đo lường khoảng cách giữa } \\
\text { mức độ kỳ vọng và mức độ cảm }\end{array}$ \\
\hline
\end{tabular}




\begin{tabular}{|c|c|c|c|}
\hline Tác giả & $\begin{array}{c}\text { Tên } \\
\text { mô hình }\end{array}$ & $\begin{array}{l}\text { Khía cạnh } \\
\text { đo lưòng }\end{array}$ & Đặc điểm \\
\hline & & $\begin{array}{l}\text { cộng sự (1988), } \\
\text { theo đó mô hình } \\
\text { nghiên cứu cũng } \\
\text { bao gồm } 5 \text { thành } \\
\text { phần: (1) Sự tin } \\
\text { cậy, (2) sự đáp ứng, } \\
\text { (3) sự đảm bảo, (4) } \\
\text { sự đồng cảm và (5) } \\
\text { phương tiện hữu } \\
\text { hình. Dựa vào sự } \\
\text { chênh lệch giữa kỳ } \\
\text { vọng và mức độ } \\
\text { thực hiện theo đánh } \\
\text { giá của khách hàng } \\
\text { là cơ sở để cải thiện } \\
\text { chất lượng dịch vụ } \\
\text { hiện tại. }\end{array}$ & $\begin{array}{l}\text { nhận về chất lượng dịch vụ, là một } \\
\text { mô hình đo lường ngắn gọn, dễ } \\
\text { hiểu. Tuy vậy khi áp dụng mô hình } \\
\text { này vào việc đánh giá chất lượng } \\
\text { dịch vụ thì quá trình nghiên cứu đòi } \\
\text { hỏi cần nhiều thời gian và chi phí } \\
\text { do phải tiến hành khảo sát hai lần, } \\
\text { lần thứ nhất là trước khi khách hàng } \\
\text { sử dụng dịch vụ và lần thứ hai là } \\
\text { sau khi khách hàng sử dụng dịch } \\
\text { vụ. }\end{array}$ \\
\hline
\end{tabular}

Nguồn: Kết quả phân tích dữ liệu của nhóm nghiên cứu

Ở các quốc gia phát triển, hoạt động xúc tiến thương mại nước ngoài chủ yếu là tổ chức triển lãm với hình thức trưng bày các sản phẩm, dịch vụ nhằm mục đích tìm kiếm đối tác mà không đặt nặng vấn đề bán hàng trực tiếp tại chỗ. Vì vậy hoạt động triển lãm ở các quốc gia này mang tính chất chuyên ngành với sản phẩm trưng bày và khách tham quan có chọn lọc. Vì lí do đó, các bài nghiên cứu liên quan đến chất lượng dịch vụ tổ chức Hội chợ, Triển lãm Thương mại còn là khái niệm khá mới và ít có bài nghiên cứu nào về lĩnh vực này. Những năm gần đây có vài nghiên cứu nước ngoài về lĩnh vực chất lượng dịch vụ tổ chức triển lãm được công bố trên các tạp chí trên thế giới như:

- Chất lượng mối quan hệ giữa đơn vị tham gia triển lãm và đơn vị tổ chức triển lãm thực trạng của ngành triển lãm tại Trung Quốc của Jin, Weber, và Bauer (2012). Kết quả nghiên cứu chỉ ra rằng chất lượng mối quan hệ giữa đơn vị tham gia triển lãm và đơn vị tổ chức triển lãm là một cấu trúc bậc hai gồm bốn yếu tố: (1) Chất lượng dịch vụ và sự hài lòng của mối quan hệ, (2) niềm tin và cam kết tình cảm, (3) truyền thông, và (4) cam kết giá trị.

- Thực trạng của chất lượng dịch vụ tổ chức triển lãm tại Taipei World Trade Centre của Lin và Lin (2014). Nhóm tác giả nghiên cứu về thực trạng của chất lượng dịch vụ triển lãm dựa trên 6 tiêu chí bao gồm: (1) Hoạt động tiếp thị cho chương trình triển lãm, (2) hoạt động thiết kế triển lãm, (3) môi trường xung quanh, (4) nhân viên cung cấp dịch vụ, (5) quản lý gian hàng triển lãm và (6) thông tin dịch vụ. Nghiên cứu này chỉ ra rằng tiêu chí hoạt động tiếp thị cho chương trình triển lãm (thông qua việc tiếp thị trên internet và thông tin đến các nhà mua hàng nước ngoài) là tiêu chí quan trọng nhất phản ánh chất lượng dịch vụ triển lãm. 
- Nghiên cứu về chất lượng dịch vụ triển lãm và mối quan hệ tương tác giữa chất lượng dịch vụ triển lãm, giá trị nhận thức, cảm xúc, sự hài lòng, và ý định hành vi thông qua việc khảo sát khách tham quan Triển lãm Giáo dục Quốc tế Ma Cao lần thứ 4 năm 2016 của Wu (2016). Kết quả nghiên cứu cho thấy có 4 yếu tố chính (chất lượng tương tác, chất lượng môi trường vật lý, chất lượng kết quả, chất lượng truy cập) và 13 phần nhỏ (hành vi của nhân viên trực gian hàng, khả năng của nhân viên trực gian hàng, ngoại cảnh, bảng chỉ dẫn và sự vệ sinh, bố cục không gian, phương tiện hữu hình, tính xã hội, thời gian chờ, giá trị nhận được, đăng ký, sự thuận tiện, thông tin, khách sạn) của chất lượng dịch vụ triển lãm được cảm nhận bởi khách tham quan triển lãm $(\mathrm{Wu}, 2016)$.

- Tính hấp dẫn của địa điểm tổ chức triển lãm - quan điểm của các nhà tổ chức và khách tham quan. Qua quá trình nghiên cứu Jin và Weber (2016) đã chỉ ra rằng các đơn vị tham gia triển lãm sẵn sàng đầu tư chi phí cho việc tham gia triển lãm ở những nơi mà họ nhận thấy được tiềm năng của thị trường. Ngược lại, khách tham quan thích những địa điểm tổ chức triển lãm thuận tiện cho việc đi lại và đặc biệt các sản phẩm dịch vụ tham gia triển lãm có khả năng hỗ trợ cho hoạt động kinh doanh hiện tại của họ, "môi trường kinh tế" và "hiệu ứng cụm ngành" của địa điểm tổ chức triển lãm tương đối ít quan trọng đối với khách tham quan. Các nhà tổ chức triển lãm đã nhận thức được sự khác biệt này và vấn đề đặt ra là làm sao để nâng cao hiệu quả tổ chức triển lãm thông qua việc đáp ứng yêu cầu của khách tham quan và các đơn vị tham gia triển lãm.

Tuy nhiên các nghiên cứu trên xét về tính chất, đối tượng khảo sát và mục đích nghiên cứu khác so với nghiên cứu đánh giá chất lượng dịch vụ tổ chức Hội chợ, Triển lãm Thương mại nước ngoài của ITPC. Tuy vậy đây cũng là nguồn thông tin tham khảo rất hữu ích trong việc xây dựng thang đo chất lượng dịch vụ tổ chức hội chợ, triển lãm thương mại nước ngoài.

Bên cạnh việc tham khảo các tài liệu nghiên cứu liên quan đến chất lượng dịch vụ tổ chức triển lãm, nghiên cứu cũng tham khảo một số nghiên cứu về chất lượng dịch vụ nhằm đánh giá điểm nổi bật và hạn chế của các nghiên cứu này, kết hợp với việc tham khảo các mô hình đánh giá chất lượng dịch vụ để đề ra khung nghiên cứu (Hình 1) đánh giá chất lượng dịch vụ tổ chức hội chợ, triển lãm thương mại nước ngoài của ITPC. 


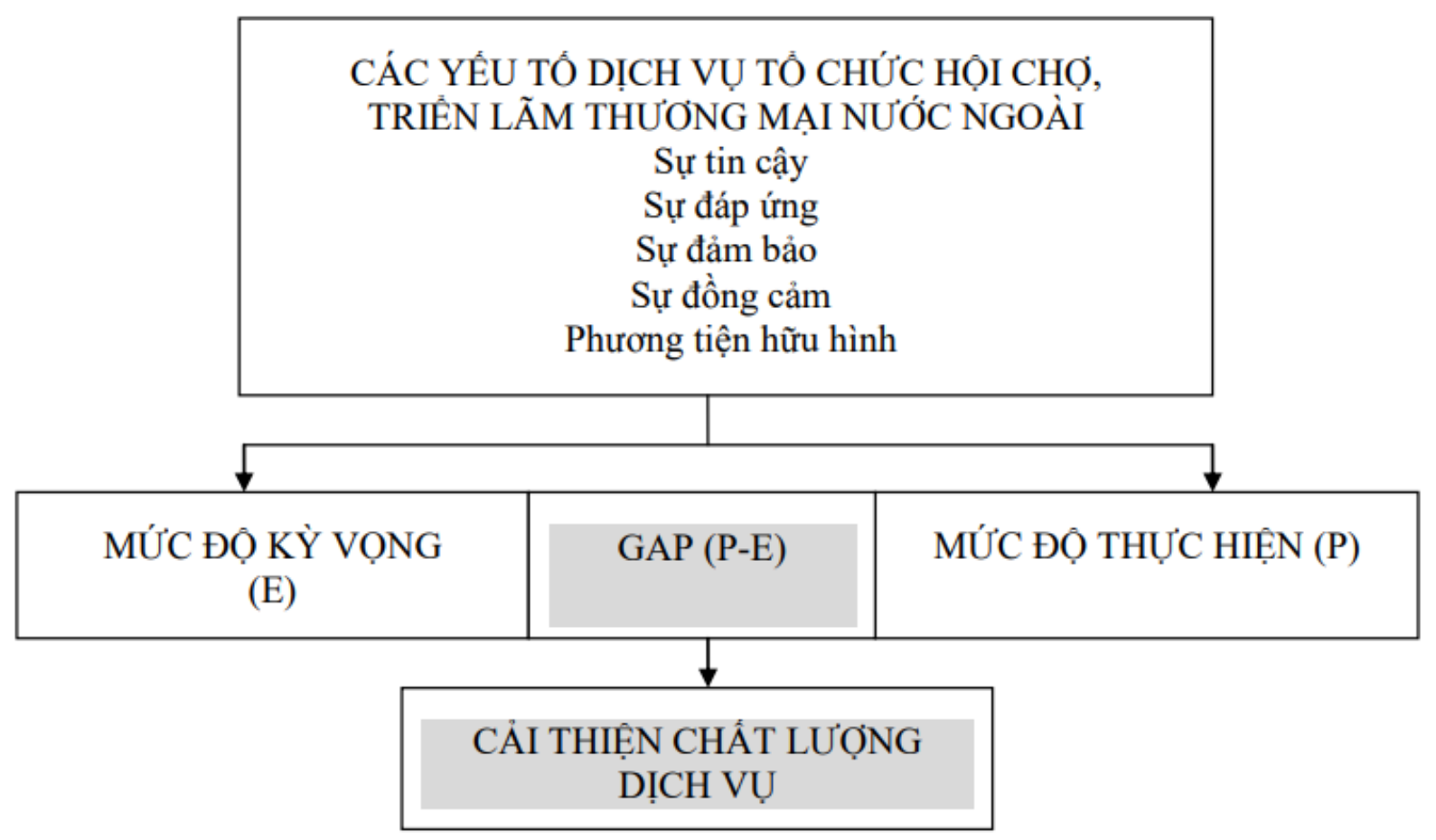

Hình 1. Khung nghiên cứu đề xuất

Trong đó:

- Sự tin cậy (reliability): Thể hiện qua khả năng thực hiện dịch vụ phù hợp và đúng thời hạn ngay từ lần đầu tiên. Sự tin cậy được thể hiện thông qua uy tín, năng lực tổ chức Hội chợ, Triển lãm Thương mại của ITPC;

- Sự đáp úng (responsiveness): Thể hiện qua sự mong muốn, sẵn sàng của nhân viên phục vụ cung cấp dịch vụ kịp thời cho khách hàng. Sự đáp ứng trong việc cung cấp dịch vụ tổ chức Hội chợ, Triển lãm Thương mại nước ngoài của ITPC thể hiện thông qua sự mong muốn, sẵn sàng hỗ trợ doanh nghiệp của nhân viên ITPC và các đơn vị hậu cần (Đơn vị lữ hành; Bộ phận dàn dựng gian hàng; Bộ phận vận chuyển hàng hóa; Bộ phận bảo trợ thông tin; Bộ phận truyền thông...);

- Sự đảm bảo (assurance): Thể hiện qua trình độ chuyên môn bao gồm kỹ năng ngoại ngữ phục vụ công tác giao tiếp với khách hàng, đối tác nước ngoài, ngoài ra còn bao gồm kỹ năng thống kê, xử lý, phân tích các dữ liệu thị trường và ngành hàng cung cấp cho các doanh nghiệp. Bên cạnh đó còn thông qua cung cách phục vụ lịch sự, niềm nở của nhân viên ITPC mỗi khi giao tiếp với các doanh nghiệp hoặc đối tác;

- Sự đồng cảm (empathy): Thể hiện sự quan tâm, chăm sóc, sẵn sàng chia sẻ những khó khăn của nhân viên ITPC đối với các doanh nghiệp;

- Phương tiện hũu hình (tangibles): Thể hiện qua ngoại hình, trang phục của nhân viên, các trang thiết bị phục vụ cho công tác tổ chức Hội chợ, Triển lãm Thương mại nước ngoài của ITPC. 


\section{Thiết kế nghiên cứu}

Thang đo đề xuất được xây dựng dựa trên thang đo SERVQUAL của Parasuraman và cộng sự (1988) với 5 yếu tố chất lượng dịch vụ: sự tin cậy, sự đáp ứng, sự đảm bảo, sự đồng cảm và phương tiện hữu hình. Trong đó: Sự tin cậy được đo lường bởi 6 biến quan sát, ký hiệu từ TC1 đến TC6; Sự đáp ứng được đo lường bởi 14 biến quan sát, ký hiệu từ DU1 đến DU14; Sự đảm bảo được đo lường bởi 5 biến quan sát, ký hiệu từ DB1 đến DB5; Sự đồng cảm được đo lường bởi 3 biến quan sát, ký hiệu từ $\mathrm{DC} 1$ đến $\mathrm{DC} 3$; Phương tiện hữu hình được đo lường bởi 12 biến quan sát, được ký hiệu từ HH1 đến HH12.

Nghiên cứu định tính lần 1 được tiến hành bằng cách phỏng vấn tay đôi 4 chuyên gia trong lĩnh vực xúc tiến thương mại của Bộ Công thương, ITPC và thảo luận nhóm 10 đại diện doanh nghiệp đã tham gia hội chợ, triển lãm thương mại nước ngoài do ITPC tổ chức với mục đích tinh chỉnh thang đo, góp ý bảng câu hỏi sao cho rõ ràng, dễ hiểu, tránh gây nhầm lẫn, góp phần tăng độ chính xác của kết quả nghiên cứu (Bảng 2).

\section{Bảng 2}

Thang đo chất lượng dịch vụ tổ chức hội chợ, triển lãm thương mại nước ngoài

\begin{tabular}{|c|c|}
\hline $\begin{array}{l}\text { STT } \\
\text { Mã }\end{array}$ & $\begin{array}{l}\text { Thang đo chính thức sau khi } \\
\text { nghiên cứu định tính lần } 1\end{array}$ \\
\hline $\begin{array}{c}1 \\
\mathrm{TC} 1\end{array}$ & ITPC là đơn vị nhà nước có uy tín trong lĩnh vực xúc tiến thương mại, đầu tư \\
\hline $\begin{array}{c}2 \\
\mathrm{TC} 2\end{array}$ & $\begin{array}{l}\text { ITPC cung cấp đầy đủ các thông tin cần thiết về Hội chợ, Triển lãm thương mại nước } \\
\text { ngoài cho doanh nghiệp }\end{array}$ \\
\hline $\begin{array}{c}3 \\
\text { TC3 }\end{array}$ & $\begin{array}{l}\text { ITPC thực hiện đúng các cam kết trong hợp đồng kinh tế đã ký với doanh nghiệp về } \\
\text { việc cung cấp dịch vụ tổ chức Hội chợ, Triển lãm Thương mại nước ngoài }\end{array}$ \\
\hline $\begin{array}{c}4 \\
\text { TC4 }\end{array}$ & $\begin{array}{l}\text { Doanh nghiệp cảm thấy tin tưởng vào chất lượng Hội chợ, Triển lãm thương mại nước } \\
\text { ngoài của ITPC tổ chức }\end{array}$ \\
\hline $\begin{array}{c}5 \\
\text { TC5 }\end{array}$ & $\begin{array}{l}\text { ITPC sắp xếp, lên kế hoạch thực hiện các công việc liên quan đến công tác tổ chức } \\
\text { Hội chợ, Triển lãm thương mại nước ngoài một cách khoa học }\end{array}$ \\
\hline $\begin{array}{c}6 \\
\text { TC6 }\end{array}$ & ITPC chuẩn bị kỹ càng trong khâu tổ chức, ít để xảy ra sai sót \\
\hline $\begin{array}{c}7 \\
\text { DU1 }\end{array}$ & $\begin{array}{l}\text { Nhân viên ITPC nhiệt tình hướng dẫn doanh nghiệp về thủ tục đăng ký, quy trình } \\
\text { tham gia Hội chợ, Triển lãm Thương mại nước ngoài }\end{array}$ \\
\hline $\begin{array}{c}8 \\
\text { DU2 }\end{array}$ & $\begin{array}{l}\text { Khi doanh nghiệp cần sự hỗ trợ hoặc tư vấn các vấn đề liên quan đến Hội chợ Triển } \\
\text { lãm Thương mại nước ngoài đều có thể liên lạc với nhân viên ITPC } 24 / 7\end{array}$ \\
\hline
\end{tabular}




\begin{tabular}{|c|c|}
\hline $\begin{array}{l}\text { STT } \\
\text { Mã }\end{array}$ & $\begin{array}{l}\text { Thang đo chính thức sau khi } \\
\text { nghiên cứu định tính lần } 1\end{array}$ \\
\hline $\begin{array}{c}9 \\
\text { DU3 }\end{array}$ & $\begin{array}{l}\text { Nhân viên ITPC luôn niềm nở tiếp nhận thông tin và hồi đáp một cách nhanh chóng } \\
\text { đến các doanh nghiệp }\end{array}$ \\
\hline $\begin{array}{c}10 \\
\text { DU4 }\end{array}$ & Nhân viên ITPC sẵn sàng cung cấp các số liệu nghiên cứu về thị trường nước ngoài \\
\hline $\begin{array}{c}11 \\
\text { DU5 }\end{array}$ & $\begin{array}{l}\text { Nhân viên ITPC sẵn sàng tư vấn khả năng tiếp cận và xâm nhập thị trường của doanh } \\
\text { nghiệp }\end{array}$ \\
\hline $\begin{array}{c}12 \\
\text { DU6 }\end{array}$ & $\begin{array}{l}\text { Các sự kiện diễn ra trong khuôn khổ Hội chợ, Triển lãm Thương mại nước ngoài đều } \\
\text { được nhân viên ITPC thông báo kịp thời đến các doanh nghiệp }\end{array}$ \\
\hline $\begin{array}{c}13 \\
\text { DU7 }\end{array}$ & $\begin{array}{l}\text { Đơn vị lữ hành - đối tác của ITPC, thực hiện công việc chuyên nghiệp và đúng với } \\
\text { hợp đồng đã ký với doanh nghiệp }\end{array}$ \\
\hline $\begin{array}{c}14 \\
\text { DU8 }\end{array}$ & $\begin{array}{l}\text { Bộ phận nghiệp vụ dàn dựng gian hàng luôn có mặt kịp thời đáp ứng các yêu cầu của } \\
\text { doanh nghiệp }\end{array}$ \\
\hline $\begin{array}{c}15 \\
\text { DU9 }\end{array}$ & $\begin{array}{l}\text { Bộ phận hậu cần vận chuyển hàng hóa doanh nghiệp tham gia Hội chợ, Triển lãm } \\
\text { thương mại nước ngoài thực hiện đúng thời gian, đảm bảo chất lượng hàng hóa }\end{array}$ \\
\hline $\begin{array}{c}16 \\
\text { DU10 }\end{array}$ & $\begin{array}{l}\text { Bộ phận bảo trợ thông tin, bộ phận truyền thông của Hội chợ, Triển lãm Thương mại } \\
\text { thực hiện tốt các công tác giới thiệu thông tin, hình ảnh về sản phẩm, dịch vụ của } \\
\text { doanh nghiệp }\end{array}$ \\
\hline $\begin{array}{c}17 \\
\text { DU11 }\end{array}$ & $\begin{array}{l}\text { ITPC tạo điều kiện để doanh nghiệp tham gia Hội chợ, Triển lãm thương mại có cơ } \\
\text { hội gặp gỡ các khách hàng, đối tác }\end{array}$ \\
\hline $\begin{array}{c}18 \\
\text { DU12 }\end{array}$ & $\begin{array}{l}\text { ITPC tạo điều kiện cho doanh nghiệp gặp gỡ, kết nối với các cơ quan ngoại giao của } \\
\text { Việt Nam (Đại sứ quán hoặc Lãnh sự quán) tại quốc gia mà ITPC tổ chức Hội chợ, } \\
\text { Triển lãm Thương mại }\end{array}$ \\
\hline $\begin{array}{c}19 \\
\text { DU13 }\end{array}$ & $\begin{array}{l}\text { ITPC hỗ trợ doanh nghiệp kết nối với chính quyền nước sở tại nhằm hỗ trợ doanh } \\
\text { nghiệp tiếp cận với những chính sách kêu gọi đầu tư, thương mại của quốc gia mà } \\
\text { ITPC tổ chức Hội chợ, Triển lãm Thương mại }\end{array}$ \\
\hline $\begin{array}{c}20 \\
\text { DU14 }\end{array}$ & $\begin{array}{l}\text { Thông tin chi tiết khách tham quan Hội chợ, Triển lãm Thương mại được ITPC thống } \\
\text { kê chi tiết và cung cấp đến doanh nghiệp sau khi kêt thúc chương trình }\end{array}$ \\
\hline $\begin{array}{c}21 \\
\text { DB1 }\end{array}$ & Nhân viên ITPC niềm nở, lịch sự và luôn lắng nghe doanh nghiệp \\
\hline 22 & Nhân viên ITPC có kiến thức sâu về thị trường, ngành hàng \\
\hline
\end{tabular}




\begin{tabular}{|c|c|}
\hline $\begin{array}{l}\text { STT } \\
\text { Mã }\end{array}$ & $\begin{array}{l}\text { Thang đo chính thức sau khi } \\
\text { nghiên cứu định tính lần } 1\end{array}$ \\
\hline DB2 & \\
\hline $\begin{array}{c}23 \\
\text { DB3 }\end{array}$ & Nhân viên ITPC luôn thể hiện sự lôi cuốn và thân thiện trong cách giao tiếp \\
\hline $\begin{array}{c}24 \\
\text { DB4 }\end{array}$ & Tiếng Anh chuyên ngành thương mại của nhân viên ITPC tốt \\
\hline $\begin{array}{c}25 \\
\text { DB5 }\end{array}$ & Các đơn vị đối tác của ITPC luôn thể hiện sự nhiệt tình, lịch sự và chuyên nghiệp \\
\hline DC1 & $\begin{array}{l}\text { Trong thời gian diễn ra Hội chợ, Triển lãm Thương mại, nhân viên ITPC thường } \\
\text { xuyên thăm hỏi các doanh nghiệp các vấn đề về doanh số bán hàng, số lượng đối tác } \\
\text { mà doanh nghiệp có cơ hội tiếp xúc hằng ngày }\end{array}$ \\
\hline $\begin{array}{c}27 \\
\mathrm{DC} 2\end{array}$ & $\begin{array}{l}\text { Nhân viên ITPC luôn chia sẻ và hỗ trợ tháo gỡ những khó khăn, thách thức mà doanh } \\
\text { nghiệp phải đối mặt trong việc tìm kiếm khách hàng, đối tác }\end{array}$ \\
\hline $\begin{array}{c}28 \\
\text { DC3 }\end{array}$ & $\begin{array}{l}\text { Nhân viên ITPC sã̃n sàng dành thời gian để lắng nghe những ý kiến góp ý của các } \\
\text { doanh nghiệp về những mặt còn hạn chế trong khâu tổ chức chương trình }\end{array}$ \\
\hline $\begin{array}{c}29 \\
\text { HH1 }\end{array}$ & $\begin{array}{l}\text { Khuôn viên tổ chức Hội chợ, Triển lãm Thương mại được đặt tại khu vực rộng, thông } \\
\text { thoáng }\end{array}$ \\
\hline $\begin{array}{c}30 \\
\mathrm{HH} 2\end{array}$ & $\begin{array}{l}\text { Khuôn viên tổ chức Hội chộ, Triển lãm Thương mại tọa lạc tại trung tâm thành phố } \\
\text { (của quốc gia tố chức Hội chợ), dễ thu hút khách tham quan }\end{array}$ \\
\hline $\begin{array}{c}31 \\
\mathrm{HH} 3 \\
\end{array}$ & $\begin{array}{l}\text { Gian hàng Hội chợ, Triển lãm thương mại nước ngoài được thiết kế theo tiêu chuẩn } \\
\text { quốc tế }\end{array}$ \\
\hline $\begin{array}{c}32 \\
\mathrm{HH} 4 \\
\end{array}$ & $\begin{array}{l}\text { Băng - rôn, cờ phướn, pano quảng cáo cho Hội chợ, Triển lãm Thương mại được thiết } \\
\text { kế đẹp, phù hợp với nội dung và tính chất của chương trình }\end{array}$ \\
\hline $\begin{array}{c}33 \\
\text { HH5 } \\
\end{array}$ & Sơ đồ hướng dẫn khách tham quan rõ ràng, được bố trí tại những vị trí dễ quan sát \\
\hline $\begin{array}{c}34 \\
\text { HH6 } \\
\end{array}$ & $\begin{array}{l}\text { Các thiết bị âm thanh, ánh sáng phục vụ Hội chợ, Triển lãm thương mại được trang bị } \\
\text { đầy đủ }\end{array}$ \\
\hline $\begin{array}{c}35 \\
\mathrm{HH} 7\end{array}$ & $\begin{array}{l}\text { Máy điều hòa, hệ thống thông gió phục vụ Hội chợ, Triển lãm thương mại được trang } \\
\text { bị đầy đủ }\end{array}$ \\
\hline
\end{tabular}




\begin{tabular}{|c|c|}
\hline $\begin{array}{l}\text { STT } \\
\text { Mã }\end{array}$ & $\begin{array}{l}\text { Thang đo chính thức sau khi } \\
\text { nghiên cứu định tính lần } 1\end{array}$ \\
\hline $\begin{array}{r}36 \\
\text { HH8 }\end{array}$ & $\begin{array}{l}\text { Khu gian nhà chung giới thiệu sản phẩm của tất cả doanh nghiệp tham gia Hội chợ } \\
\text { Triền lãm Thương mại được thiết kế, trang trí hài hòa về mặt bố cục và nổi bật về mặt } \\
\text { hình thức }\end{array}$ \\
\hline $\begin{array}{c}37 \\
\text { HH9 }\end{array}$ & $\begin{array}{l}\text { Khu vực dành cho doanh nghiệp kết nối } \mathrm{B} 2 \mathrm{~B} \text { trong khuôn khổ Hội chợ được bố trí } \\
\text { riêng biệt, yên tĩnh, có bàn kêt nồi riêng cho từng doanh nghiệp nhằm đảm bảo sự bảo } \\
\text { mật thông tin }\end{array}$ \\
\hline $\begin{array}{r}38 \\
\text { HH10 } \\
\end{array}$ & Trang phục nhân viên ITPC luôn lịch sự, chỉnh tề \\
\hline $\begin{array}{c}39 \\
\text { HH11 }\end{array}$ & $\begin{array}{l}\text { Công tác an ninh, bảo vệ, phòng cháy chữa cháy tại Hội chợ Triển lãm Thương mại } \\
\text { được đảm bảo }\end{array}$ \\
\hline $\begin{array}{r}40 \\
\mathrm{HH} 12\end{array}$ & $\begin{array}{l}\text { ITPC phát hành Kỷ yếu hội chợ bao gồm các thông tin liên hệ, logo, sản phẩm, dịch } \\
\text { vụ của tất cả doanh nghiệp tham gia Hội chợ Triển lãm Thương mại nước ngoài do } \\
\text { ITPC tổ chức }\end{array}$ \\
\hline
\end{tabular}

Nguồn: Kết quả phân tích dữ liệu của nhóm nghiên cứu

Nghiên cứu định lượng được tiến hành bằng cách phỏng vấn đại diện 220 doanh nghiệp (trưởng đoàn tham gia hội chợ, triển lãm thương mại nước ngoài của từng doanh nghiệp) tham gia hội chợ, triển lãm thương mại nước ngoài do ITPC tổ chức từ tháng 01/2017 đến tháng 08/2017 tại Lào, Myanmar, Campuchia. Theo T. D. Nguyen (2013), với 40 biến quan sát và thang đo Likert 5 mức độ, kích thước mẫu tối thiểu là $n=40$ x $5=200$. Các doanh nghiệp đã được phỏng vấn theo phương pháp phi xác suất thuận tiện tại Buổi phổ biến nội dung và quy định tham gia Hội chọ, Triển lãm Thuoong mại (thường được ITPC tổ chức 10 ngày trước chương trình) để đo lường mức độ kỳ vọng $(\mathrm{E})$ của doanh nghiệp về chất lượng dịch vụ và phỏng vấn trực tiếp (50\%), qua điện thoại $(25 \%)$ hoặc e-mail $(25 \%)$ để đo lường mức độ thực hiện dịch vụ $(\mathrm{P})$ sau 7 ngày kết thúc chương trình.

Số liệu được xử lý bằng phần mềm SPSS 20.0 theo 5 bước: Mã hóa bảng hỏi và nhập liệu sau đó tiến hành làm sạch dữ liệu; Kiểm tra độ tin cậy của thang đo (hệ số Cronbach's Alpha > 0,7 theo Hoang Trong \& Chu, 2008); Phân tích nhân tố khám phá (EFA); Sử dụng phương pháp thống kê mô tả, các trị số trung bình để đánh giá mức độ kỳ vọng và mức độ thực hiện dịch vụi; Sử dụng phương pháp so sánh cặp (Paired-samples T-test) để kiểm định sự chênh lệch giữa mức độ kỳ vọng và mức độ thực hiện dịch vụ và cuối cùng là sử dụng phương pháp kiểm định Independent samples T-test để kiểm định sự khác biệt mức độ kỳ vọng về chất lượng dịch vụ giữa các loại hình và quy mô doanh nghiệp.

Sau khi thu được kết quả nghiên cứu định lượng (200/220 bảng khảo sát hợp lệ), nhóm tác giả tiến hành nghiên cứu định tính lần 2 bằng cách thảo luận nhóm cùng với 5 chuyên gia và 5 đại diện doanh nghiệp với mục đích thảo luận kết quả nghiên cứu, đề xuất các hàm ý quản trị nhằm nâng cao chất lượng dịch vụ tổ chức hội chợ, triển lãm thương mại nước ngoài. 


\section{Kết quả nghiên cứu và thảo luận}

\section{1. Độ tin cậy của thang đo}

Qua quá trình kiểm định Cronbach's Alpha các biến quan sát trong tập dữ liệu về mức độ kỳ vọng của doanh nghiệp, biến quan sát DB3_E bị loại khỏi thang đo do không đảm bảo độ tin cậy.

Đồng thời, cũng qua quá trình kiểm định Cronbach's Alpha các biến quan sát trong tập dữ liệu về mức độ thực hiện dịch vụ, các biến quan sát DU1_P, DU2_P, DU6_P, DU8_P, DB3_P, HH9_P, HH12_P bị loại khỏi thang đo do không đảm bảo độ tin cậy.

Để tiến hành các bước phân tích tiếp theo, thang đo chất lượng tổ chức hội chợ, triển lãm thương mại nước ngoài phải đảm bảo độ tin cậy khi đo lường đồng thời mức độ kỳ vọng và mức độ thực hiện dịch vụ. Do đó thang đo tổng quát loại bỏ 7 biến quan sát bao gồm: DU1, DU2, DU6, DU8, DB3, HH9 và HH12.

Ba mươi ba biến quan sát trong tập dữ liệu về mức độ kỳ vọng của doanh nghiệp và tập dữ liệu về mức độ thực hiện dịch vụ sau khi tiến hành phân tích nhân tố đều đã trích được 5 nhóm nhân tố với giá trị Eigenvalue > 1 và giá trị tổng phương sai trích tương ứng là $72 \%$ và $70 \%$ (đều lớn hơn $50 \%$ ) vì vậy kết quả phân tích nhân tố khám phá là phù hợp. Tất cả 33 biến quan sát trong tập dữ liệu về mức độ kỳ vọng của doanh nghiệp và mức độ thực hiện dịch vụ đều có hệ số tải nhân tố lớn hơn 0,5. Trong ma trận nhân tố sau khi xoay (Bảng 3), sự tập trung của các biến quan sát theo từng nhân tố được thể hiện rõ ràng, thang đo đảm bảo tính hội tụ.

\section{Bảng 3}

Kết quả kiểm định Cronbach's Alpha và phân tích nhân tố

\begin{tabular}{|c|c|c|c|c|c|c|c|c|c|c|c|}
\hline \multicolumn{6}{|c|}{ Tập dữ liệu mức độ kỳ vọng } & \multicolumn{6}{|c|}{ Tập dữ liệu mức độ thực hiện dịch vụ } \\
\hline & \multicolumn{5}{|c|}{ Nhóm nhân tố } & & \multicolumn{5}{|c|}{ Nhóm nhân tố } \\
\hline & 1 & 2 & 3 & 4 & 5 & & 1 & 2 & 3 & 4 & 5 \\
\hline Alpha & $\begin{array}{c}0,91 \\
2\end{array}$ & $\begin{array}{c}0,86 \\
6\end{array}$ & $\begin{array}{c}\mathbf{0 , 8 2} \\
8\end{array}$ & $\begin{array}{c}0,84 \\
1\end{array}$ & $\begin{array}{c}0,91 \\
9\end{array}$ & Alpha & $\begin{array}{c}0,78 \\
2\end{array}$ & $\begin{array}{c}\mathbf{0 , 8 8} \\
3\end{array}$ & $\begin{array}{c}\mathbf{0 , 7 7} \\
8\end{array}$ & $\begin{array}{c}0,77 \\
8\end{array}$ & $\mathbf{0 , 8 2 0}$ \\
\hline TC1_E & .758 & & & & & TC1_P & .714 & & & & \\
\hline TC2_E & .876 & & & & & TC2_P & .879 & & & & \\
\hline TC3_E & .726 & & & & & TC3_P & .714 & & & & \\
\hline TC4_E & .951 & & & & & TC4_P & .706 & & & & \\
\hline TC5_E & .748 & & & & & TC5_P & .769 & & & & \\
\hline TC6_E & .933 & & & & & TC6_P & .823 & & & & \\
\hline DU3_E & & .860 & & & & DU3_P & & .866 & & & \\
\hline DU4_E & & .927 & & & & DU4_P & & .824 & & & \\
\hline DU5_E & & .824 & & & & DU5_P & & .812 & & & \\
\hline DU7_E & & .775 & & & & DU7_P & & .769 & & & \\
\hline DU9_E & & .746 & & & & DU9_P & & .701 & & & \\
\hline $\begin{array}{c}\text { DU10_ } \\
\text { E }\end{array}$ & & .805 & & & & $\begin{array}{c}\text { DU10_ } \\
\mathbf{P}\end{array}$ & & .866 & & & \\
\hline
\end{tabular}




\begin{tabular}{|c|c|c|c|c|c|c|c|c|c|c|c|}
\hline \multicolumn{6}{|c|}{ Tập dữ liệu mức độ kỳ vọng } & \multicolumn{6}{|c|}{ Tập dữ liệu mức độ thực hiện dịch vụ } \\
\hline & \multicolumn{5}{|c|}{ Nhóm nhân tố } & & \multicolumn{5}{|c|}{ Nhóm nhân tố } \\
\hline & 1 & 2 & 3 & 4 & 5 & & 1 & 2 & 3 & 4 & 5 \\
\hline Alpha & $\begin{array}{c}0,91 \\
2\end{array}$ & $\begin{array}{c}\mathbf{0 , 8 6} \\
6\end{array}$ & $\begin{array}{c}0,82 \\
8\end{array}$ & $\begin{array}{c}\mathbf{0 , 8 4} \\
1\end{array}$ & $\begin{array}{c}0,91 \\
9\end{array}$ & Alpha & $\begin{array}{c}\mathbf{0 , 7 8} \\
2\end{array}$ & $\begin{array}{c}\mathbf{0 , 8 8} \\
\mathbf{3}\end{array}$ & $\begin{array}{c}\mathbf{0 , 7 7} \\
8\end{array}$ & $\begin{array}{c}\mathbf{0 , 7 7} \\
8\end{array}$ & $\mathbf{0 , 8 2 0}$ \\
\hline $\begin{array}{c}\text { DU11_ } \\
\text { E }\end{array}$ & & .717 & & & & $\begin{array}{c}\text { DU11_ } \\
\text { P }\end{array}$ & & .723 & & & \\
\hline $\begin{array}{c}\text { DU12 } \\
\text { E }\end{array}$ & & .863 & & & & $\begin{array}{c}\text { DU12 } \\
\text { P }\end{array}$ & & .852 & & & \\
\hline $\begin{array}{c}\text { DU13_ } \\
\text { E }\end{array}$ & & .873 & & & & $\begin{array}{c}\text { DU13 } \\
\mathbf{P}\end{array}$ & & .777 & & & \\
\hline $\begin{array}{c}\text { DU14 } \\
\text { E }\end{array}$ & & .812 & & & & $\begin{array}{c}\text { DU14 } \\
\text { P }\end{array}$ & & .698 & & & \\
\hline DB1_E & & & .868 & & & DB1_P & & & .822 & & \\
\hline DB2_E & & & .924 & & & DB2_P & & & .914 & & \\
\hline DB4_E & & & .908 & & & DB4_P & & & .903 & & \\
\hline DB5_E & & & .892 & & & DB5_P & & & .812 & & \\
\hline DC1_E & & & & .947 & & DC1_P & & & & .912 & \\
\hline DC2_E & & & & .942 & & DC2_P & & & & .901 & \\
\hline DC3_E & & & & .915 & & DC3_P & & & & .899 & \\
\hline HH1_E & & & & & .920 & HH1_P & & & & & .720 \\
\hline HH2_E & & & & & .925 & HH2_P & & & & & .815 \\
\hline HH3_E & & & & & .893 & HH3_P & & & & & .733 \\
\hline HH4_E & & & & & .897 & HH4_P & & & & & .779 \\
\hline HH5_E & & & & & .910 & HH5_P & & & & & .826 \\
\hline HH6_E & & & & & .864 & HH6_P & & & & & .820 \\
\hline HH7_E & & & & & .901 & HH7_P & & & & & .777 \\
\hline HH8_E & & & & & .882 & HH8_P & & & & & .812 \\
\hline HH10_E & & & & & .728 & HH10_P & & & & & .819 \\
\hline HH11_E & & & & & .711 & HH11_P & & & & & .780 \\
\hline
\end{tabular}

Nguồn: Kết quả phân tích dữ liệu của nhóm nghiên cứu

Nhân viên nhiệt tình hướng dẫn thủ tục đăng ký, quy trình tham gia, luôn giữ liên lạc 24/7, nhân viên thông báo kịp thời các sự kiện diễn ra trong khuôn khổ chương trình, bộ phận nghiệp vụ dàn dựng gian hàng luôn có mặt kịp thời để đáp ứng các yêu cầu của doanh nghiệp, được thể hiện qua các biến quan sát DU1, DU2, DU6, DU8, các hoạt động này thể hiện sự đáp ứng của ITPC trong việc cung ứng dịch vụ tổ chức hội chợ, triển lãm thương mại nước ngoài đến các doanh nghiệp. Bên cạnh đó việc thể hiện sự lôi cuốn và thân thiện trong cách giao tiếp với doanh nghiệp (DB3) cũng góp phần phản ánh sự đảm bảo trong việc cung ứng dịch vụ. Đồng thời việc thiết kế khu vực gian nhà chung (HH9), công tác an ninh, chữa cháy (HH12) là các yếu tố hữu hình không thể thiếu của một hội chợ, triển lãm thương mại. Tuy nhiên sau quá trình kiểm định Cronbach's Alpha và phân tích nhân tố thì 7 biến quan sát này đều bị loại do 
không đảm bảo độ tin cậy. Theo kết quả thảo luận nhóm tại nghiên cứu định tính lần 2, việc loại 7 biến quan sát này là phù hợp với thực trạng nghiên cứu, do các nguyên nhân sau:

- Đối với các biến DU1, DU2, DU6, DB3: Tiền thân của ITPC là Trung tâm Phát triển Ngoại thương được thành lập từ năm 1968. Là tổ chức xúc tiến thương mại có thâm niên và uy tín nên các hoạt động hỗ trợ doanh nghiệp được ITPC rất chú tâm. Vì vậy, nhân viên luôn được nhắc nhở thể hiện sự nhiệt tình, năng nổ và thân thiện trong cách giao tiếp, luôn đặt sự hài lòng của doanh nghiệp lên hàng đầu. Bên cạnh đó, nhiều đơn vị xúc tiến thương mại đã ra đời và cạnh tranh gay gắt, do đó, các yếu tố này là thiết yếu và phải được đáp ứng tốt thì doanh nghiệp mới đồng hành lâu dài cùng đơn vị tổ chức. Vì vậy, các biến quan sát này không nhất thiết phải đưa vào trong thang đo;

- Với biến DU8: Các rủi ro về điện, bảng tên gian hàng, bàn, ghế, kệ trưng bày, ánh sáng... tại các gian hàng hội chợ, triển lãm thương mại nước ngoài rất thường hay xảy ra, nếu xử lý không kịp thời sẽ ảnh hưởng rất lớn đến chất lượng chương trình. Các đơn vị tổ chức lúc nào cũng chú trọng đến hoạt động này; do đó, đối với các doanh nghiệp, hoạt động này là hết sức bình thường và họ có thể được đáp ứng bởi bất kỳ nhà tổ chức nào, nhất là với ITPC;

- Với biến HH9: Khu gian nhà chung giới thiệu sản phẩm của tất cả doanh nghiệp chủ yếu chỉ giới thiệu vào một ngày khai mạc chương trình với mục đích tạo không gian để các đại biểu cấp cao tham quan về hoạt động sản xuất, thương mại, du lịch của TP.HCM. ITPC là đơn vị đầu tiên và duy nhất lên ý tưởng xây dựng gian nhà chung nên yếu tố này còn khá mới mẻ, nhiều doanh nghiệp chưa cảm thấy cần thiết;

- Với biến HH12: Đây là quy định bắt buộc hàng đầu của các địa phương tổ chức, nên các doanh nghiệp hầu như không quan ngại về công tác này, đặc biệt là khi ITPC tổ chức.

\subsection{Chất lự̆ng dịch vụ tổ chức hội chọ̆, triển lãm thuơng mại nước ngoài của ITPC}

Với độ tin cậy 95\%, giá trị Sig. > 0,05 nên không có sự khác biệt về mức độ thực hiện và mức độ kỳ vọng của doanh nghiệp $(\mathrm{P}=\mathrm{E})$ đối với 9/33 yếu tố: TC1, TC2, TC3, TC4, TC5, TC6, HH1, HH5, HH7. Các yếu tố này đạt yêu cầu mà doanh nghiệp kỳ vọng.

Bên cạnh đó, với độ tin cậy $95 \%$, kết quả kiểm định cho thấy có sự khác biệt về mức độ thực hiện và mức độ kỳ vọng của doanh nghiệp (Sig. < 0,05 ), cụ thể là mức độ thực hiện cao hơn mức độ kỳ vọng $(\mathrm{P}>\mathrm{E})$ dao động từ 0,1 đến 0,5 , thể hiện qua 12/33 yếu tố: DU3, DB1, DB5, DC1, DC2, DC3, HH2, HH3, HH6, HH8, HH10, HH11. Kết quả tích cực này cho thấy, chất lượng dịch vụ tổ chức hội chợ, triển lãm thương mại nước ngoài của ITPC đáp ứng kỳ vọng của doanh nghiệp trong nhiều yếu tố.

Cũng với độ tin cậy $95 \%$ (giá trị Sig. < 0,05), kết quả kiểm định cho thấy có 12/33 yếu tố mà ITPC thực hiện thấp hơn so với mức độ kỳ vọng của doanh nghiệp $(\mathrm{P}<\mathrm{E})$ : DU4, DU5, DU7, DU9, DU10, DU11, DU12, DU13, DU14, DB2, DB4, HH4. Các yếu tố này cần phải được lãnh đạo ITPC tập trung cải thiện nhằm nâng cao chất lượng dịch vụ tổ chức các hội chợ, triển lãm thương mại nước ngoài đáp ứng được sự kỳ vọng của doanh nghiệp. 


\subsection{Kiểm định sục khác biệt về giá trị kỳ vọng trung bình}

\section{Bảng 4}

Sự khác biệt giữa doanh nghiệp lớn với doanh nghiệp nhỏ và vừa

\begin{tabular}{|l|c|c|}
\hline Quy mô doanh nghiệp & Số lượng & Giá trị kỳ vọng trung bình \\
\hline Doanh nghiệp lớn & 90 & 3,75 \\
\hline Doanh nghiệp nhỏ và vừa & 110 & 3,90 \\
\hline Mức chênh lệch kỳ vọng & & 0,15 \\
\hline Sig. (Levene's test) & & 0,221 \\
\hline Sig. (T-test) & & 0,009 \\
\hline
\end{tabular}

Nguồn: Kết quả xử lý bằng phần mềm SPSS 20

Theo số liệu từ Bảng 5 , nhóm doanh nghiệp có quy mô nhỏ và vừa kỳ vọng cao hơn nhóm doanh nghiệp có quy mô lớn với mức chênh lệch là 0,15 . Theo báo cáo của Tổng cục thống kê (2017), tính đến ngày 31/12/2016, Việt Nam có trên 97\% là doanh nghiệp vừa và nhỏ, trong đó gần $60 \%$ doanh nghiệp có quy mô rất nhỏ với hạn chế về vốn cũng như điều kiện kỹ thuật, hiệu quả kinh doanh chưa cao. Vì vậy, khi chi phí một khoản lớn để tham gia hội chợ, triển lãm thương mại nước ngoài, họ phải cân nhắc rất kỹ tính hiệu quả và thiết thực của chương trình. Họ kỳ vọng rất cao về khả năng thực hiện dịch vụ phù hợp và đúng thời hạn, về sự lắng nghe, chia sẻ, tư vấn của nhân viên ITPC, về phương tiện hữu hình phục vụ công tác tổ chức.

\section{Bảng 5}

Sự khác biệt giữa nhóm doanh nghiệp $100 \%$ vốn tư nhân và nhóm doanh nghiệp có vốn đầu tư nhà nước

\begin{tabular}{|l|c|c|}
\hline Loại hình doanh nghiệp & Số lượng & Giá trị kỳ vọng trung bình \\
\hline DN có vốn đầu tư nhà nước & 70 & 3,71 \\
\hline DN 100\% vốn tư nhân & 130 & 3,90 \\
\hline Mức chênh lệch kỳ vọng & & 0,19 \\
\hline Sig. (Levene's test) & & 0,062 \\
\hline Sig. (T-test) & \multicolumn{2}{|l|}{0,002} \\
\hline
\end{tabular}

Nguồn: Kết quả xử lý bằng phần mềm SPSS 20

Theo số liệu từ Bảng 6, nhóm doanh nghiệp $100 \%$ vốn tư nhân kỳ vọng cao hơn nhóm doanh nghiệp có vốn đầu tư nhà nước với mức chênh lệch là 0,19 . Những doanh nghiệp có vốn đầu tư nhà nước thường có xu hướng chủ quan trong hoạt động quản lý và kinh doanh vì một phần kinh phí đã có sự bảo trợ của nhà nước. Họ thường sử dụng kinh phí nhà nước tham gia các hoạt động xúc tiến thương mại như hội chợ, triển lãm thương mại nước ngoài nên mức độ kỳ vọng thấp hơn so với các doanh nghiệp 100\% vốn tư nhân. 


\section{Kết luận và hàm ý quản trị}

Có 12 trên tổng số 33 biến quan sát đánh giá chất lượng dịch vụ tổ chức hội chợ, triển lãm thương mại nước ngoài của ITPC theo doanh nghiệp có mức độ thực hiện thấp hơn so với mức độ kỳ vọng $(\mathrm{P}<\mathrm{E})$, phần lớn thuộc hai yếu tố Sự đáp ứng và Sự đảm bảo. Ba nhóm hàm ý quản trị được đề xuất nhằm cải thiện 12 yếu tố này.

- Nhóm 1: Các yếu tố thuộc sự đáp ứng (DU4, DU5, DU7, DU9, DU10, DU11, DU12, DU13, DU14)

○ Trước khi diễn ra hội chợ, triển lãm thương mại nước ngoài, cần có một buổi chia sẻ thông tin về thị trường quốc gia sẽ tổ chức sự kiện nhằm giúp doanh nghiệp nắm được những thông tin cơ bản về thị trường, làm cơ sở ra quyết định chính xác;

○ Thành lập tổ nghiên cứu thị trường. Phát hành Bản tin nghiên cứu thị trường, ngành hàng cung cấp cho doanh nghiệp;

○ Thẩm tra khả năng cung ứng dịch vụ của các đơn vị hậu cần thông qua hồ sơ năng lực trước khi quyết định chọn nhà thầu;

o Tổ chức một buổi làm việc giữa ITPC, các đơn vị hậu cần và các doanh nghiệp tham gia hội chợ, triển lãm thương mại nước ngoài. Đây là dịp để các bên trao đổi, hiểu rõ nhau hơn, làm cơ sở để thực hiện đúng theo yêu cầu của doanh nghiệp;

○ Cử nhân viên giám sát việc cung ứng dịch vụ hỗ trợ của các đơn vị này, đảm bảo đúng chất lượng như đã cam kết với doanh nghiệp trong hợp đồng;

○ Trong hợp đồng mà ITPC ký kết với các đơn vị hậu cần, cần bổ sung mục xử phạt nếu không thực hiện đúng như hợp đồng dịch vụ đã ký;

○ Chú trọng hoạt động truyền thông trước, trong và sau hội chợ, triển lãm thương mại nước ngoài;

○ Các đơn vị bảo trợ thông tin, truyền thông trong và ngoài nước cần có sự phối hợp chặt chẽ và thống nhất về mặt nội dung truyền thông;

○ Cần xem xét yếu tố văn hóa, đặc tính mỗi vùng miền của mỗi quốc gia mà lựa chọn cách thức truyền thông khác nhau;

o Thiết kế ra một biểu mẫu để doanh nghiệp điền thông tin chi tiết đối tượng khách hàng, đối tác mong muốn tìm kiếm. Tập hợp tất cả thông tin yêu cầu của doanh nghiệp gởi đến các đơn vị hỗ trợ ITPC mời đúng đối tượng;

○ Cung cấp thông tin liên hệ của khách hàng, đối tác nước ngoài để các doanh nghiệp Việt Nam có bước làm việc trước nhằm giúp tiết kiệm thời gian, chi phí;

○ Tổ chức hoạt động gặp gỡ các cơ quan ngoại giao của Việt Nam ở nước ngoài, tạo cơ hội cho doanh nghiệp tiếp cận với các chính sách hỗ trợ thương mại từ các cơ quan này;

o Thiết lập một kênh giải đáp thắc mắc của doanh nghiệp về thị trường nước ngoài; tổ chức các buổi hội thảo, chia sẻ thông tin, chính sách thu hút đầu tư, thương mại, với sự tham dự của các doanh nghiệp Việt Nam, đại diện chính quyền nước sở tại và cơ quan ngoại giao của Việt Nam đặt tại nước sở tại;

o Trang bị hệ thống xử lý, thống kê thông tin chi tiết của khách tham quan;

o Thu thập thông tin danh thiếp tất cả doanh nghiệp nước ngoài tham gia; tiến hành thống kê, phân loại theo ngành hàng để cung cấp cho các doanh nghiệp Việt Nam.

- Nhóm 2: Các yếu tố thuộc sự đảm bảo (DB2, DB4) 
○ Mở các lớp học nội bộ nhằm nâng cao kiến thức cho nhân viên trẻ về nghiên cứu thị trường với giảng viên là các chuyên gia có nhiều kinh nghiệm trong lĩnh vực;

o Tăng cường hoạt động liên kết với các cơ quan đại diện thương mại (Thương vụ), Phòng Thương mại và Công nghiệp Việt Nam (VCCI), Cục Xúc tiến Thương mại (Viettrade), các viện nghiên cứu, Hiệp hội DN Thành phố, các tổ chức xúc tiến thương mại, hiệp hội nước ngoài tại Việt Nam nhằm chia sẻ, cử nhân viên đi học hỏi kinh nghiệm kinh doanh, xúc tiến thương mại và nghiên cứu thị trường quốc tế;

○ Chủ động hoặc liên kết với các đơn vị khác mở lớp học Anh văn thương mại, tạo điều kiện cho nhân viên nâng cao trình độ ngoại ngữ chuyên ngành với kinh phí được trích ra một phần từ nguồn thu của đơn vị;

o Đề xuất nhân sự tham gia các chương trình đào tạo tiếng Anh cho cán bộ, viên chức thành phố do Sở Nội vụ tổ chức hằng năm.

- Nhóm 3: Yếu tố thuộc phương tiện hữu hình (HH4)

○ Tăng kinh phí cho hoạt động thiết kế, in ấn Kỷ yếu hội chợ, triển lãm thương mại nước ngoài;

o Lựa chọn các đơn vị thiết kế để có các mẫu thiết kế Kỷ yếu đẹp;

o In màu Kỷ yếu, đồng thời đảm bảo thể hiện đầy đủ thông tin về liên lạc, logo, sản phẩm của tất cả doanh nghiệp tham gia chương trình.

Qua kết quả kiểm định sự khác biệt có thể thấy việc hỗ trợ các doanh nghiệp có $100 \%$ nguồn vốn tư nhân và các doanh nghiệp có quy mô nhỏ và vừa trong hoạt động xúc tiến thương mại nước ngoài là hết sức cần thiết. Nghiên cứu đề xuất các hàm ý quản trị nhằm tăng cường sự hỗ trợ các doanh nghiệp có $100 \%$ nguồn vốn tư nhân và đặc biệt là các doanh nghiệp có quy mô nhỏ và vừa trong hoạt động xúc tiến thương mại nước ngoài theo đúng tinh thần Nghị quyết số 35/NQ-CP của Chính phủ (2016) về việc hỗ trợ phát triển doanh nghiệp đến năm 2020, cụ thể như sau:

- Đề xuất giảm chi phí tham gia Hội chợ, Triển lãm Thương mại nước ngoài cho các doanh nghiệp có quy mô nhỏ và vừa, áp dụng cho các doanh nghiệp là hội viên của các Hiệp hội, Hội ngành nghề trong nước. Một mặt tăng cường sự liên kết giữa ITPC và các đơn vị Hiệp hội, Hội ngành nghề trong hoạt động xúc tiến thương mại, đầu tư. Mặt khác các Hiệp hội, Hội ngành nghề là đơn vị quản lý chặt thông tin chi tiết về các hội viên, đảm bảo việc hỗ trợ của ITPC là hiệu quả và đúng đối tượng;

- Phối hợp với các Hiệp hội, Hội ngành nghề trong nước thông tin đến doanh nghiệp có quy mô nhỏ và vừa các chương trình hỗ trợ xúc tiến thương mại nước ngoài do Cục Xúc tiến Thương mại (Vietrade), Ủy ban Nhân dân Thành phố Hồ Chí Minh tổ chức;

- Tổ chức các buổi đối thoại giữa doanh nghiệp với chính quyền Thành phố Hồ Chí Minh (Cục Thuế, Cục Hải quan, Sở Công thương, Sở Kế hoạch và Đầu tư, Trung tâm Xúc tiến Thương mại và Đầu tư...) nhằm tháo gỡ những khó khăn, vướng mắc của doanh nghiệp trong hoạt động kinh doanh đồng thời các buổi đối thoại cũng là một kênh để truyền đạt thông tin đến doanh nghiệp về các chính sách hỗ trợ thương mại, đầu tư.

- Bên cạnh đó, hoạt động kết nối với các Thương vụ Việt Nam tại nước ngoài (Cơ quan trực thuộc Bộ Công thương có trụ sở tại nước ngoài thực hiện chức năng nghiên cứu, cung cấp 
thông tin thị trường về quốc gia mà cơ quan này đặt trụ sở) cũng cần được chú trọng. Đây là kênh thông tin hữu ích, giúp doanh nghiệp định hình được thị trường muốn tiếp cận.

Các nghiên cứu tương lai về chất lượng dịch vụ tổ chức hội chợ, triển lãm thương mại nước ngoài của ITPC cần tiến hành khảo sát tất cả các doanh nghiệp tham gia chương trình với thành phần đáp viên ngoài trưởng đoàn cần có thêm người đại diện theo pháp luật của doanh nghiệp thì nghiên cứu sẽ đạt độ chính xác cao hơn, từ đó hỗ trợ doanh nghiệp Việt Nam xúc tiến thương mại một cách hiệu quả cao nhất.

\section{Tài liệu tham khảo}

Chính phủ. (2009). Nghị định về trọ giúp phát triển doanh nghiệp nhỏ và vìra. Nghị định 56/2009/NĐ-CP ngày 30/06/2009 [Decree on assistance to the development of small and medium enterprises. Decree 56/2009 / ND-CP dated 30/06/2009]. Retrieved May 15, 2017 , from http://www.chinhphu.vn/portal/page/portal/chinhphu/hethongvanban?class_id=1\&mode $=$ detail\&document_id=88612

Cronin, J., \& Taylor, S. (1992). Measuring service quality: A reexamination and extension. Journal of Marketing, 6(5), 55-68.

Gronroos, C. (1984). A service quality model and its marketing implications. European Journal of Marketing, 18(4), 36-44.

Gronroos, C. (1990). Service management and marketing: Managing the moment of truth in service competition. New York, NY: Maxwell Macmillan Internal Editions.

Hoang Trong, \& Chu, N. M. N. (2008). Phân tích dũ liệu nghiên cứu với SPSS [Analyze research data with SPSS]. Ho Chi Minh, Vietnam: Nhà xuất bản Thống Kê.

Jin, X., Weber, K., \& Bauer, T. (2012). Relationship quality between exhibitors and organizers: A perspective from Mainland China's exhibition industry. International Journal of Hospitality Management, 31(4), 1222-1234.

Jin, X., \& Weber, K. (2016). Exhibition destination attractiveness - Organizers' and visitors' perspectives. International Journal of Contemporary Hospitality Management, 28(12), 2795-2819.

Kotler, P. (2003). Marketing management (11th ed.). Upper Saddle River, NJ: Prentice-Hall.

Kotler, P., \& Armstrong, G. (2010). Principles of marketing (13th ed.). Upper Saddle River, NJ: Pearson Education.

Kotler, P., Veronica, W., John, S., \& Gary, A. (2005). Principles of marketing (4th ed.). Upper Saddle River, NJ: Prentice Hall.

Kumar, G., Manjunath, S., \& Kumar, H. (2012). A study of retail service quality in organized retailing. International Journal of Engineering and Management Sciences, 3(3), 370-372. 
Kumar, M., Kee, F. T., \& Manshor, A. T. (2009). Determining the relative importance of critical factors in delivering service quality of banks; An application of dominance analysis in SERVQUAL model. Managing Service Quality, 19(2), 211-228.

Lin, C., \& Lin, W. (2014). Exhibitor perspectives of exhibition service quality in Taipei world trade centre. Journal of Convention \& Event Tourism, 14(4), 293-308.

Malhotra, N., Ulgado, F., Agarwal, J., \& Shainesh, W. (2005). Dimensions of service quality in developed economies: Multi-country cross-cultural comparisons. International Marketing Review, 22(3), 256-278.

Nguyen, T. D. (2013). Phưong pháp nghiên cúu khoa hoc trong kinh doanh [Scientific research method in business]. Hanoi, Vietnam: Nhà xuất bản Tài chính.

Nguyen, T. M. T. (2006). Chất lượng dịch vụ, sự thỏa mãn và lòng trung thành, của khách hàng siêu thị tại Thành phố Hồ Chí Minh [Service quality, satisfaction and loyalty, of customers in Ho Chi Minh City supermarket]. Tạp chí Phát triển Khoa học và Công nghệ, 9(10), 57-70.

Nguyen, T. V., Hong, B. B., \& Nguyen, V. T. T. (2016). Ảnh hưởng của chất lượng các dịch vụ hỗ trợ sinh viên đến hình ảnh trường Đại học. Một nghiên cứu tại Trường Đại học Bách Khoa Thành phố Hồ Chí Minh [The impact of the quality of student support services on the image of the University. A study at Ho Chi Minh City University of Technology]. Tạp chí khoa học Đại học Mở Thành phố Hồ Chí Minh, 3(48), 114-126.

Nguyen, V. T. A. (2015). Kiểm định thang đo chất lượng dịch vụ đại học tại Thành phố Hồ Chí Minh [Testing the service quality scale of universities in Ho Chi Minh City]. Tap chí Khoa học Giáo dục Kỹ thuật, 33(12), 25-32.

Parasuraman, A., Zeithaml, A., \& Berry, L. L. (1985). A conceptual model of service quality and its implications for future research. Journal of Marketing, 49(3), 41-50.

Parasuraman, A., Zeithaml, A., \& Berry, L. L. (1988). SERVQUAL: A multiple item scale for measuring customer perceptions of service quality. Journal of Retailing, 64(1), 13-40.

Phan, A. C., Nguyen, H. T., \& Nguyen, M. H. (2016). Chất lượng dịch vụ và lòng trung thành của khách hàng Nghiên cứu tình huống các cửa hàng tiện ích tại Hà Nội [Service quality and customer loyalty A case study of convenience stores in Hanoi]. Tạp chí Khoa hoc ĐHQGHN: Kinh tế và kinh doanh, 32(1), 11-21.

Quốc hội. (2015). Luật thuơng mại. Luật số 36/2005/QH11 ngày 14/06/2005 [Commercial law. Law No. 36/2005 / QH11 dated June 14, 2005]. Retrieved May 15, 2017, from https://thukyluat.vn/vb/luat-thuong-mai-2005-36-2005-qh11-a49.html

Tổng cục Thống kê. (2017). Doanh nghiệp Việt đang yếu dần [Vietnamese businesses are weakening]. Retrieved May 18, 2017, from http://kinhtedothi.vn/doanh-nghiep-vietdang-yeu-dan-285311.html 
Trung tâm Xúc tiến Thương mại và Đầu tư Thành phố Hồ Chí Minh. (2016). Các bước tổ chức Hội chợ, Triển lãm Thương mại nước ngoài [Steps to organize foreign trade fairs and exhibitions]. Bản tin Xúc tiến Thưong mại và Đầu tu, 28(1), 12-18.

Wu, H. C. (2016). A study of exhibition service quality, perceived value, emotion, satisfaction, and behavioral intentions. Event Management, 20(1), 565-591.

Zeithaml, V., \& Bitner, M. (2000). Services marketing: Integrating customer focus across the firm. Boston, MA: McGraw-Hill. 